УДК 656.078

UDC 656.078

Попович П.В. ${ }^{1}$, Побережний Л.Я. ${ }^{2}$, Мурований I. С. ${ }^{3}$, Шевчук О.С. ${ }^{1}$, Прогній П. Б. ${ }^{1}$, ПобережнаЛ.Я.' ${ }^{2}$, Плотиця В.М. ${ }^{4}$

${ }^{1}$ Західноукраӥнський національний університет, Тернопіль, Украӥна; ${ }^{2}$ Івано - Франківський національний технічний університет нафти і газу, Івано - Франківськ, Украӥна; ${ }^{3}$ Луцький національний технічний університет, Луцьк, Украйна; ${ }^{4}$ Тернопільський національний технічний університет імені Івана Пулюя, Тернопіль, Украӥна

\title{
ДОСЛІДЖЕННЯ КОМФОРТУ В ГРОМАДСЬКОМУ ТРАНСПОРТІ М. ТЕРНОПОЛЯ
}

\begin{abstract}
Незважаючи на те, що комфорт є одним із найважливіших факторів формування попиту на громадський транспорт, чинником зручності часто нехтується при проектуванні транспортних мереж, а також при оцінці експлуатаційних показників. В міських пасажирських перевезеннях, зокрема для середніх міст, вибір пасажирами виду транспорту для поїздок залежить, окрім тривалості подорожі, також від множини важливих показників. Для покращення розуміння кількісних та якісних показників при використанні громадського транспорту транспортна послуга повинна бути розроблена так, щоб вона відповідала рівню очікуваних клієнтами послуг, що забезпечить оптимальну капіталізацію при реалізації транспортної послуги. Дане дослідження $\epsilon$ основою формування політики перевезень пасажирів громадським транспортом 3 позиції максимального комфорту населення 3 розробкою основ вимірювання сприйняття найважливіших факторів зручності громадського транспорту, мінімального дискомфорту i максимальної безпеки. На базі проведених натурних досліжень 3 застосуванням визначників дискомфорту i вагових коефіцієнтів визначено кількісні показники сприйняття комфорту в мережі громадського транспорту м. Тернополя, що може бути використано для прогнозування поведінки пасажирів в користуванні міським громадським транспортом. Визначено, що сумарний рівень комфортності в системі громадського транспорту м.Тернополя $є$ змінним в залежності від багатьох факторів, найважливішим 3 яких $\epsilon$ щільність пасажирів в салоні транспортного засобу натовпу в години пік, хоча для оптимального проектування мереж громадського транспорту доцільно враховувати всю множину показників комфорту. Результати дослідження є основою розуміння відношення пасажирів і сприйняття комфорту при послугах міського громадського транспорту, їх може бути використано як інструмент при плануванні і експлуатації транспортних мереж середніх міст.
\end{abstract}

Ключові слова: пасажирські перевезення, маршрут, рівень комфорту, громадський транспорт, пасажиропотік.

\section{ВСТУП}

В пасажирських перевезеннях вибір пасажирами виду транспорту для їхніх поїздок залежить, окрім тривалості подорожі, також від багатьох інших показників. Для покращення розуміння кількісних а також якісних показників при поїздках громадським транспортом дана послуга повинна бути спроектована и запропонована таким чином, щоб вона відповідала рівню очікуваних пасажирами послуг, це забезпечить оптимальні прибутки при продажі поїздки перевізником. Отже, доцільним $\epsilon$ проведення досліджень сприйняття пасажирами якості поїздок та удосконалення політики перевезень населення громадським транспортом 3 оцінкою комфорту у системі громадського транспорту середніх міст шляхом використання множини якісних i кількісних показників. Важливим буде встановити забезпечення можливості більш повного розуміння ставлення пасажирів до сприйняття якості транспортної послуги як фактору зручності послуг міського пасажирського транспорту.

\section{АНАЛІЗ ВІДОМИХ РЕЗУЛЬТАТІВ ДОСЛІДЖЕНЬ. ПОСТАНОВКА ПРОБЛЕМИ}

3 метою збільшення рівня безпеки, а також зменшення рівня дискомфорту у громадському транспорті, транспортна послуга має проектуватися таким чином, щоб відповідність очікуванням пасажирів була максимально адекватною [1 - 9]. Проведені дослідження з використанням моделі дискомфорту дозволяють коректно прогнозувати вибір пасажирами виду транспорту також їхню 
поведінку при користуванні громадським транспортом у середніх містах, проте вони мають ряд суттєвих недоліків - дослідження пасажиропотоків проведено з застосуванням непрямих методів, використовуючи інформацію операторів стільникового зв'язку, також дані диспетчерських служб [9, $10,11,12]$, на цій основі виникатиме ряд суттєвих похибок як наслідок неточностей та припущень. Комфорт громадського транспорту в країнах Євросоюзу контролюється стандартом якості EN 13816 стандарт обслуговування в громадському транспорті, який оцінює рівень задоволеності пасажирів за переліком таких факторів як зручність, доступність, інформування, час/тривалість, обслуговування клієнтів, комфорт їзди, безпека та вплив на навколишнє середовище. Стандарт ISO 2631-1 регулює дотримання механічних показників (рівень шуму від кочення коліс, ін.), тому він використовується при проектуванні транспортних засобів. Загальновідомо, в Україні при проектуванні транспортних мереж до уваги приймаються тільки тривалість поїздки пасажира до пункту призначення. Незважаючи на те, що зручність пасажирів і безпека є базовими факторами попиту для громадського транспорту, таким показником, як зручність в нас зазвичай нехтується при проектуванні транспортних систем середніх міст, хоча на практиці вибір пасажирами громадського транспорту визначається багатьма чинниками.

\section{ЦЛЬ ТА ЗАДАЧІ ДОСЛІДЖЕННЯ}

На території України налічується близько 66 міст [3, 4], які можна віднести до категорії середніх [3], площа міст 3 чисельністю мешканців від 50000 - 250000 чоловік становить до 65 квадратних кілометрів. Для такого міста, як Тернопіль, основним пасажиропотокам властиві діаметральні, або радіальні напрямки, щільність населення знаходиться в межах 113,1 чол./кв.км. За інформацією $[5,6,7,8]$, місто має 38 транспортних районів, загальна кількість автобусних маршрутів громадського транспорту становить 37, вони обслуговуються 197 од. автобусів, кількість зупиночних пунктів - 218 од., загальна довжина автобусної маршрутної мережі - 647, 7 км. Встановлено, автобусний парк громадського транспорту комплектується транспортними засобами малої пасажиромісткості типу “Богдан А092”, “Еталон”, кожен з яких має місткість 42 пасажири. У пікові години по всій мережі громадського транспорту спостерігали перевантаження транспорту коефіцієнт заповнення становив більше 100\%, причому середньодобовий коефіцієнт знаходився в межах 60-80\%.

Відомо, при міських пасажирських перевезеннях рекомендується дотримуватись заповнення салону автобуса відповідно до передбаченої конструкцією транспортного засобу максимальної кількості пасажирів. Таке навантаження транспортного засобу позитивно впливатиме на навантаження металоконструкції та ходової частини, осей розширюючи зони комфортності коливання шин, збільшуючи ресурс роботи транспортних засобів [10, 12-16]. Необхідно вдосконалювати політику міських перевезень населення для досягнення оптимального рівня комфорту у громадському транспорті. Показниками рівня комфорту населення при використанні громадського транспорту у проектуванні транспортної мережі міста практично не враховуються, завжди нехтуються, особливо при пасажирських перевезеннях у середніх містах, вважаючи, що такий показник, як час їздки буде єдиним показником який впливатиме на вибір пасажиром виду транспорту [9- 11]. Дослідження було проведено двома етапами робіт - камеральному, а також експериментальному - проведено збір та обробку даних, отриманих у результаті обстеження пасажирських потоків. Суцільні натурні дослідження табличним методом, який, в порівнянні 3 існуючими, є найбільш трудомістким, проте єдиним, який може забезпечити максимальну точність інформації про пасажирів для подальшої камеральної обробки отриманих статистичних даних досліджуваної системи автобусних маршрутів громадського транспорту м. Тернополя. Важливо, що дані дослідження пасажиропотоків на автобусних маршрутах міського громадського транспорту в м. Тернополі проведено як суцільні натурні дослідження табличним методом. Для здійснення аналізу досліджуються шість обертових рейсів на кожному діючому маршруті транспортної мережі міста у періоди: піковий ранковий - з 6.30- 10.00 год., міжпіковий - 310.00 до 16.00 год., піковий вечірній - 3 16.00 до 19.30 год. Досліджено особливості зміни пасажиропотоку по годинах доби, днях тижня, нерівномірність пересування пасажирів у часі і просторі по місту з початкової до кінцевої зупинки, а також оцінка основних пересадочні пункти міста, спосіб оплати за проїзд: готівковий чи безконтактний, пільговий. Період досліджень - 7 календарних днів, з 04.11.19 по 11.11.19 року, зміни пасажиропотоку визначаються окремо у робочі і вихідні дні. Час проведення: 6.30 - 19.30 год. В салоні перебував один обліковець, працюючи у маршрутному транспортному засобі починаючи 3 першої зупинки, розміщуючись за задніми дверима автобуса. Всі одержані дані по пасажирообігу і способу оплати, а також інформацію про вид транспорту, на якому проводяться дослідження, номер 
маршруту, напрямок руху транспортного засобу - прямий чи зворотній напрям, час початку i закінчення рейсу, час руху автобуса між зупинками, марку рухомого складу, обліковець самостійно, по факту записував у сформовану дослідниками картку обліку. Дослідженнями мережі громадського транспорту м.Тернополя, визначено основні базові показники мобільності пасажирів, які можуть бути характерними для середніх міст, що добре корелює 3 [17], наприклад, більше нуля, менше 45, в ідеалі 16 - кількість хвилин, яку пасажири вважають за краще проводити на маршрутах, згідно 3 дослідженнями.

Отже:

- швидкість притоку пасажирів на зупинку у між пікові періоди 1пас/хв, у години пік 4 пас/хв.;

- час очікування транспортного засобу до 10 хв.;

- час поїздки від периферійних районів до центру 30-35 хв. ;

- час поїздки між периферійними районами до 60 хв.;

- години пік ранкові 8.00-9.00 год., вечірні 16.30-18.30 год.;

- розрахункова швидкість переміщення пасажирів у автобусах міста 15-20 км/год.

Одержана інформація була внесена для подальшого опрацювання у сформовану спеціальну карту обліку, потім проводилися обчислення для ділянок руху між зупиночними пунктами кожного досліджуваного маршруту (табл. 1)

Таблиця 1. Досліджувані маршрути громадського транспорту у м. Тернополі

\begin{tabular}{|c|c|c|c|c|c|c|}
\hline №3/П & $\begin{array}{c}\text { № } \\
\text { маршр } \\
\text { уту }\end{array}$ & Найменування маршруту & $\begin{array}{c}\text { Довжина } \\
\text { маршрут } \\
\text { у, } \\
\text { км } \\
\end{array}$ & Час & Інтерв., хв & $\begin{array}{l}\text { Кільк. тр. } \\
\text { засобів на } \\
\text { маршр., } \\
\text { шт. }\end{array}$ \\
\hline 1 & 2 & 3 & 5 & 6 & 7 & 8 \\
\hline 1 & $1 \mathrm{~A}$ & Винниченка-Слівенська & 6,1 & $06: 12-21: 25$ & 8 & 8 \\
\hline 2 & 2 & Миру-Бродівська & 10,29 & $06: 12-20: 20$ & 40 & 2 \\
\hline 3 & 3 & Миру-Міська лікарня №2 & 9,32 & $06: 10-21: 26$ & $8 \mathrm{xB}$ & 5 \\
\hline 4 & 4 & Лесі Українки-Новий світ & & $06: 39-08: 48$ & 52 & 1 \\
\hline 5 & 5 & $\begin{array}{c}\text { Лучаківського-В. } \\
\text { Березовиця } \\
\end{array}$ & 11,69 & $06: 00-20: 42$ & 17 & 4 \\
\hline 6 & $5 \mathrm{~A}$ & $\begin{array}{c}\text { Лучаківського- село } \\
\text { Острів }\end{array}$ & 14,87 & $06: 08-21: 05$ & 24 & 4 \\
\hline 7 & 6 & Новий Світ-Автовокзал & 4,36 & $06: 55-21: 16$ & 16 & 4 \\
\hline 8 & $6 \mathrm{~A}$ & Новий Світ-Автовокзал & & $06: 34-21: 37$ & 52 & 1 \\
\hline 9 & 7 & $\begin{array}{c}\text { Автовокзал-Обласна } \\
\text { дитяча лікарня }\end{array}$ & 7,88 & $06: 15-21: 01$ & 12 & 6 \\
\hline 10 & 8 & $\begin{array}{c}\text { С. Біла - Містечко } \\
\text { Шляховиків }\end{array}$ & 15,5 & $05: 54-22: 52$ & 8 & 10 \\
\hline 11 & 9 & Новий Світ-Автовокзал & 8,56 & 06:04-09:08 & 52 & 1 \\
\hline 12 & 11 & $\begin{array}{c}\text { Довженка- Обласна } \\
\text { психоневрологічна } \\
\text { лікарня }\end{array}$ & 10,43 & $06: 07-22: 41$ & 12 & 6 \\
\hline 13 & 12 & Карпенка- Протасевича & 8,97 & $05: 52-20: 54$ & 8 & 9 \\
\hline 14 & 13 & Симоненка- Автовокзал & 6,98 & $05: 58-23: 52$ & 5 & 10 \\
\hline 15 & 14 & $\begin{array}{c}\text { Автовокзал- Лесі } \\
\text { Українки }\end{array}$ & 6,75 & $06: 34-22: 44$ & 6 & 11 \\
\hline 16 & 15 & Злуки- Миру & 8,43 & $06: 10-22: 50$ & 7 & 9 \\
\hline 17 & 16 & Київська- Винниченка & 9,23 & $05: 58-23: 52$ & 7 & 11 \\
\hline 18 & 17 & $\begin{array}{c}\text { СелоКутківці- } \\
\text { Автовокзал }\end{array}$ & 4,88 & $06: 12-21: 15$ & 60 & 1 \\
\hline 19 & 18 & $\begin{array}{c}\text { ТРЦ «Подоляни»- } \\
\text { Містечко Шляховиків }\end{array}$ & 18,87 & $05: 57-23: 53$ & 7 & 15 \\
\hline 20 & 19 & $\begin{array}{c}\text { ТРЦ «Подоляни» } \\
\text { Винниченка }\end{array}$ & 12,08 & $06: 33-22: 57$ & 7 & 11 \\
\hline
\end{tabular}




\begin{tabular}{|c|c|c|c|c|c|c|}
\hline \multicolumn{7}{|c|}{ Продовження таблиці 1} \\
\hline 1 & 2 & 3 & 5 & 6 & 7 & 8 \\
\hline 21 & 20 & Київська- Автовокзал & 7,01 & $05: 43-22: 31$ & 8 & 8 \\
\hline 22 & 22 & $\begin{array}{c}\text { ТРЦ «Подоляни» } \\
\text { Автовокзал }\end{array}$ & 7,61 & $05: 34-22: 08$ & 6 & 10 \\
\hline 23 & $22 \mathrm{~A}$ & $\begin{array}{l}\text { ТРЦ «Подоляни» } \\
\text { Автовокзал }\end{array}$ & & $06: 14-21: 38$ & 64 & 1 \\
\hline 24 & 23 & $\begin{array}{c}\text { Село Пронятин } \\
\text { Автовокзал }\end{array}$ & 8,03 & $05: 52-21: 00$ & 30 & 3 \\
\hline 25 & 25 & $\begin{array}{c}\text { Золотогірська- Лесі } \\
\text { Українки }\end{array}$ & 9,36 & $06: 02-22: 50$ & 10 & 6 \\
\hline 26 & 26 & $\begin{array}{c}\text { Лучаківського- БГ } \\
\text { «Епіцентр» }\end{array}$ & 10,73 & $06: 24-09: 39$ & 25 & 3 \\
\hline 27 & 27 & $\begin{array}{c}\text { Обласна } \\
\text { психоневрологічна } \\
\text { лікарня- Симоненка }\end{array}$ & 10,17 & $06: 20-22: 37$ & 9 & 9 \\
\hline 28 & 28 & Ринок- Лучаківського & 3,91 & $08: 42-17: 31$ & 13 & 3 \\
\hline 29 & 29 & Вербицького- Автовокзал & 3,69 & $06: 12-19: 30$ & 11 & 5 \\
\hline 30 & 30 & $\begin{array}{c}\text { Обласна } \\
\text { психоневрологічна } \\
\text { лікарня- } \\
\text { Корольова }\end{array}$ & 10,17 & $10: 00-18: 20$ & 15 & 5 \\
\hline 31 & 31 & $\begin{array}{c}\text { Містечко Шляховиків- } \\
\text { Міська лікарня №3 }\end{array}$ & 12,58 & $\begin{array}{l}\text { 06:57-20:40, у } \\
\text { вихідні до 19:30 }\end{array}$ & 28 & 3 \\
\hline 32 & 32 & $\begin{array}{c}\text { Мазепи- Міське } \\
\text { кладовище }\end{array}$ & & $10: 12-16: 40$ & 60 & 1 \\
\hline 33 & 33 & $\begin{array}{c}\text { Видавництво «Збруч»- } \\
\text { Обласний геріатричний } \\
\text { будинок-інтернат }\end{array}$ & 6,7 & $06: 24-20: 30$ & 30 & 2 \\
\hline 34 & 34 & $\begin{array}{c}\text { Міська лікарня №2- } \\
\text { Село Біла }\end{array}$ & 7,06 & $06: 24-19: 37$ & $\begin{array}{l}31 \\
51\end{array}$ & 2 \\
\hline 35 & 35 & Винниченка- Винниченка & 12,5 & $06: 07-20: 34$ & 10 & 8 \\
\hline 36 & 36 & $\begin{array}{c}\text { Міська лікарня №2- } \\
\text { Автовокзал }\end{array}$ & 8,35 & 07:03-18:09 & $\begin{array}{l}33 \\
66 \\
\end{array}$ & 2 \\
\hline 37 & 85 & $\begin{array}{c}\text { Село Гаї Шевченківські- } \\
\text { Автовокзал }\end{array}$ & & $07: 00-21: 00$ & 90 & 1 \\
\hline
\end{tabular}

Проведеними дослідженнями встановлено, ступінь безконтактної (банківські картки, гугл пей) оплати за проїзд становив від $60 \%$ до $74 \%$ загального числа пасажирів, які оплачували проїзд, за винятком пільгових категорій населення, при пасажирських перевезеннях на маршрутах громадського транспорту у місті. Визначено, що час руху транспортного засобу між ділянками маршрутів, для всіх досліджуваних, знаходився у межах 2 -2,3 хвилини, в залежності від дорожньої обстановки, де межами ділянок є зупинки громадського транспорту. Мультикретеріальним аналізом транспортної мережі встановлено: коефіцієнт пересадочності пасажирів 1,1; коефіцієнт непрямолінійності 1, 76; середній час очікування 5,8 хв.; маршрутний коефіцієнт 4,60; середній час пересування 33 хв.; середня відстань пересування 4,3 км., що корелює 3 даними, одержаними дещо раніше [5].

\section{РЕЗУЛЬТАТИ ДОСЛІДЖЕННЯ}

Оптимальним для формування політики міських перевезень населення громадським транспортом 3 позиції оптимізації за критерієм оптимального рівня комфорту при раціональній завантаженості $\epsilon$ застосування даних досліджень найскладнішого 3 позиції максимальної завантаженості маршруту (рис. 1) при перевезеннях населення міста за показниками найбільшої кількості пасажирів, відстані та часу перевезення, який лімітує одночасне перебування в закритому просторі - салоні маршрутного транспортного засобу людей. Для даного маршруту коефіцієнт непрямолінійності, середній час очікування, середній час пересування, середня відстань пересування є вищими від вказаних вище середніх значень. Встановлено, що таким є маршрут, що з'єднує два периферійні райони на діаметрально протилежних сторонах міста Тернопіль, №18. 

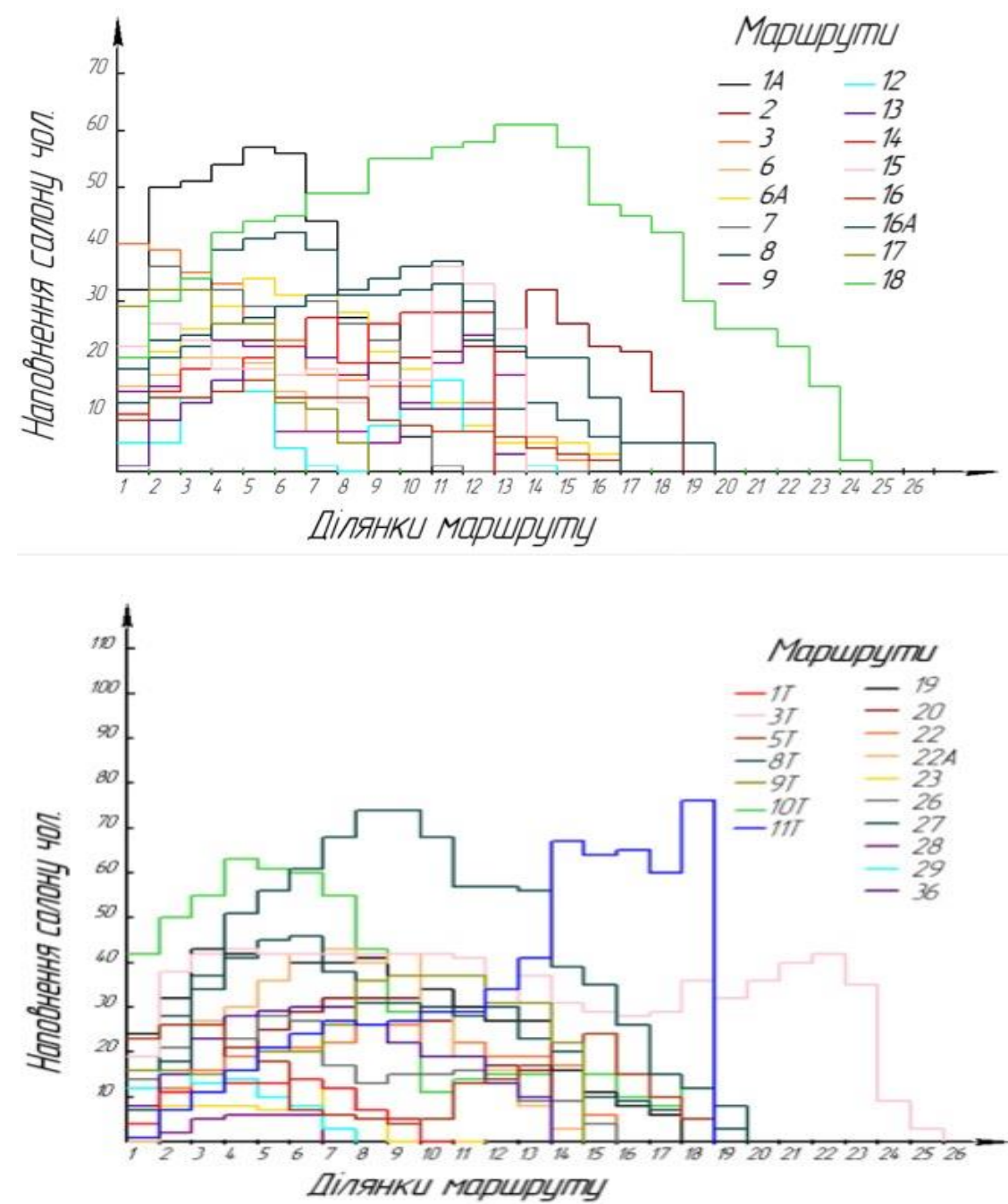

Рисунок 1. Нерівномірність пасажиропотоку для вказаного транспортного засобу за ділянками маршруту

В [9] функція рівня переповненості як функція дискомфорту розраховується з урахуванням пасажиромісткості транспортних засобів, враховуючи кількість місць для сидіння $\mathrm{i}$ тривалість поїздки. Розглядувалися різні варіанти поїздок, при першому вільних сидячих місць не було, при другому було одне місце для сидіння і при третьому варіанті пасажиромісткість транспортного засобу за рахунок великої кількості пасажирів використовувалася на 100\%. В роботі [10] запропоновано оцінювання переповненості шляхом вимірювання рівня переповненості за значенням коефіцієнта навантаження і кількості стоячих пасажирів на один квадратний метр, хоча часто такий показник нормований і враховується виробниками транспортних засобів ще на етапі проектування. При тому, що умовне порогове значення - одиниця буде перевищене, функція дискомфорту ростиме за експоненціальним законом [10]. Можливо, раціональним також буде апроксимувати закон зміни функції дискомфорту поліномом третього (четвертого) степеня моделюючи дану ситуацію.

Для відображення сприйняття пасажирами рівня комфорту у громадському транспорті, в [11] моделюється лінійне підвищення рівня дискомфорту до порогового значення і при його перевищенні 3 наступним зростанням за експоненціальним законом.

Рівень дискомфорту, рис.2, 3, є функцією розрахункової щільності пасажирів в транспортному засобі [11]

$$
x=\left\{\begin{array}{cc}
\alpha \\
e^{\alpha}
\end{array} \text { if }{ }_{\alpha>1}^{\alpha \leq 1}(1)\right.
$$

де рівень кількості пасажирів в транспортному засобі (х) обчислюється на основі показника $\alpha$ 


$$
\alpha=\frac{\text { Number of passengers in vecicle }}{\text { Vecicle capacity }}
$$
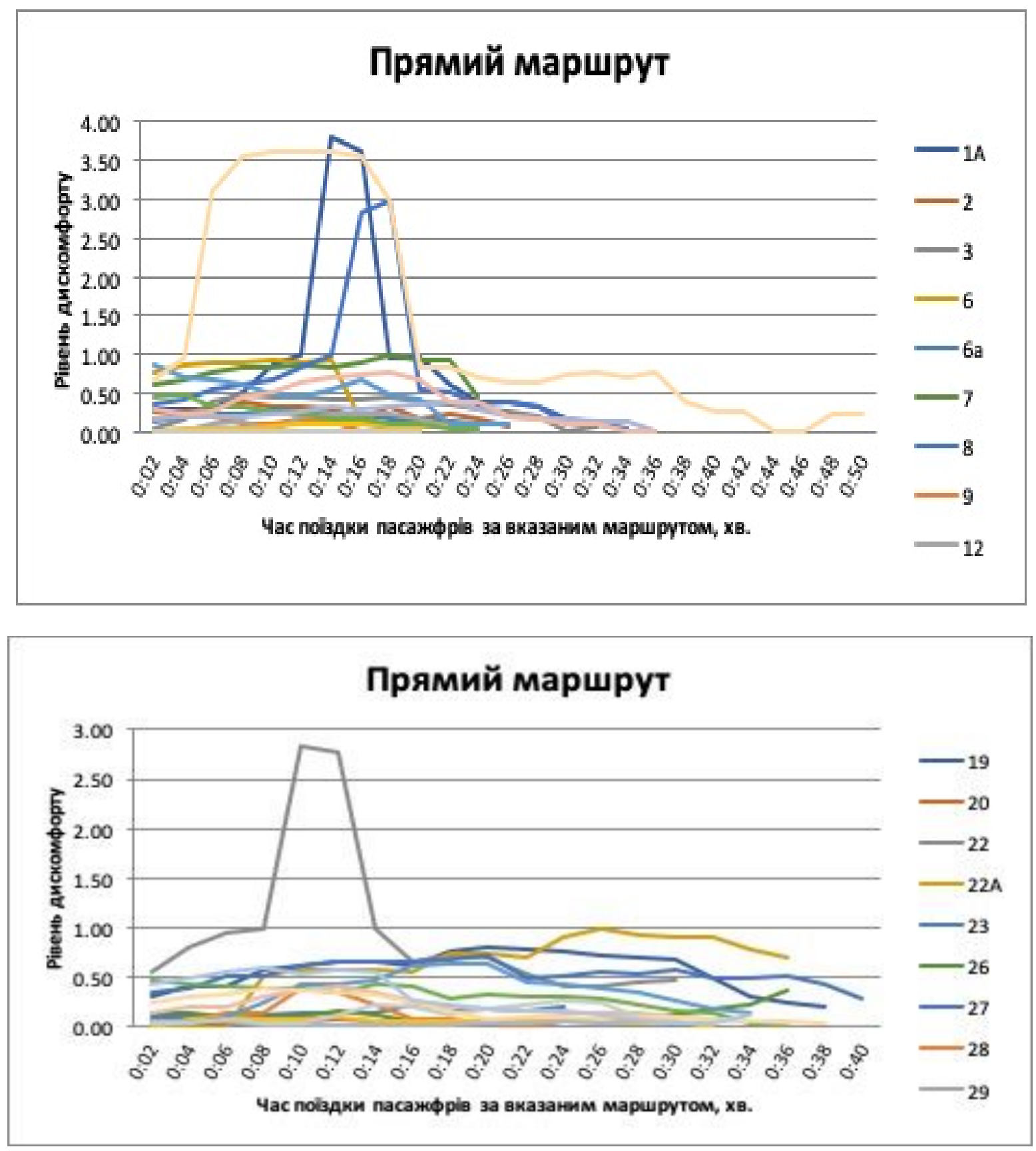

Рисунок 2. Загальний рівень дискомфорту як функція щільності пасажирів за часом у поїздці маршрутом громадського пасажирського транспорту: прямі маршрути 

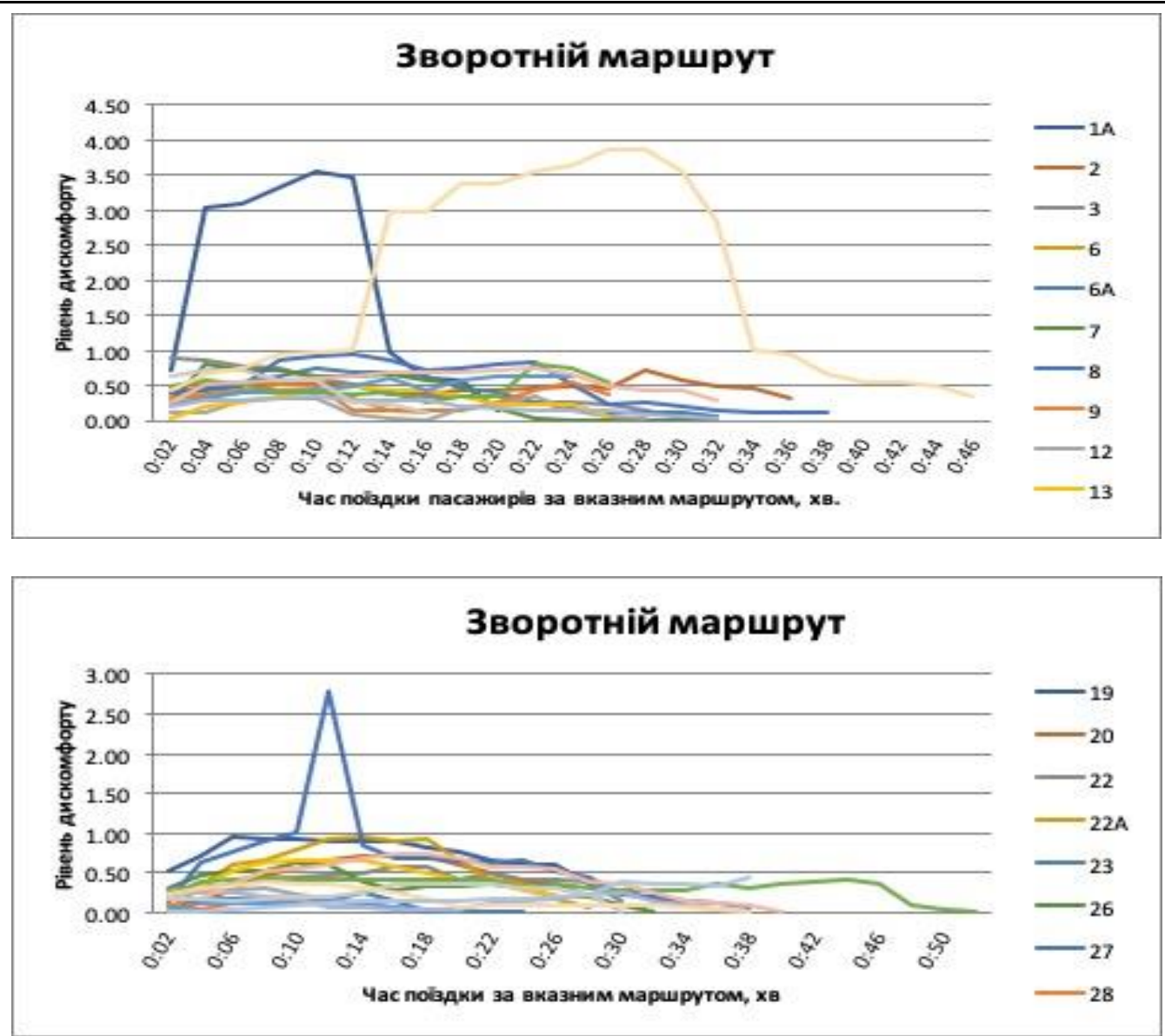

Рисунок 3. Загальний рівень дискомфорту як функція щільності пасажирів за часом у поїздці маршрутом громадського пасажирського транспорту: зворотні маршрути

При реалізації (1), (2), на рис. 2,3,4 представлено графічне зображення загального рівня дискомфорту як функції щільності пасажирів в транспортному засобі в часі поїздки дослідженими маршрутами вказаного виду транспорту для прямої та зворотної поїздок.

Для подальшого оцінювання дискомфорту рекомендовано методу зважених сум, функція набуватиме кусково-лінійної форми, рівень сумарного дискомфорту пасажирів що знаходяться в салоні транспортного засобу в процесі транспортування [11]

$$
f(x)=\sum_{i} w_{i} \cdot x_{i t}(3)
$$

де $x_{i t}$ - значення $i$-го визначника дискомфорту в $t$-й відлік часу, $w_{i}$ - величина $i$-го вагового коефіцієнта, $x_{i t}$ обчислюється з (1).

За даними обліковців, якими проведено опитування у м. Тернополі, встановлено, що важливим при виборі пасажиром транспортного засобу, а також маршруту з можливих, є показник комфорту від сидіння, їхати стоячи у салоні опитані пасажири бажали менше. 3 урахуванням даних опитування, а також даних досліджень Şükrü İmre and Dilay Çelebi [11] для нас прийнято значення комфорту від сидіння $\quad 0.0556$, що, очевидно, корелює з комфорту від сидіння 0.0615 для Т1 та комфорту від сидіння 0.0762 для М2 [11]. Отже, значення вагових коефіцієнтів важливості: скупченість у транспортному засобі 0.4053 ; температура повітря в салоні транспортного засобу 0.2243 ; комфорт від сидіння $\quad 0.0556$, інформування і вказівки 0.0590 ; чистота в транспортному засобі $\quad 0.1324$; технічний стан ТЗ $0.0899 ;$ поломки 0.0335 [11].

ОБГОВОРЕННЯ РЕЗУЛЬТАТІВ ДОСЛІДЖЕНЬ

Компонентний аналіз рівня дискомфорту відповідно маршрутів мережі громадського пасажирського транспорту проведений для маршрутів на яких встановлене умовне порогове значення - одиниця - було перевищене (рис. 4): 1А, 18, 22. 


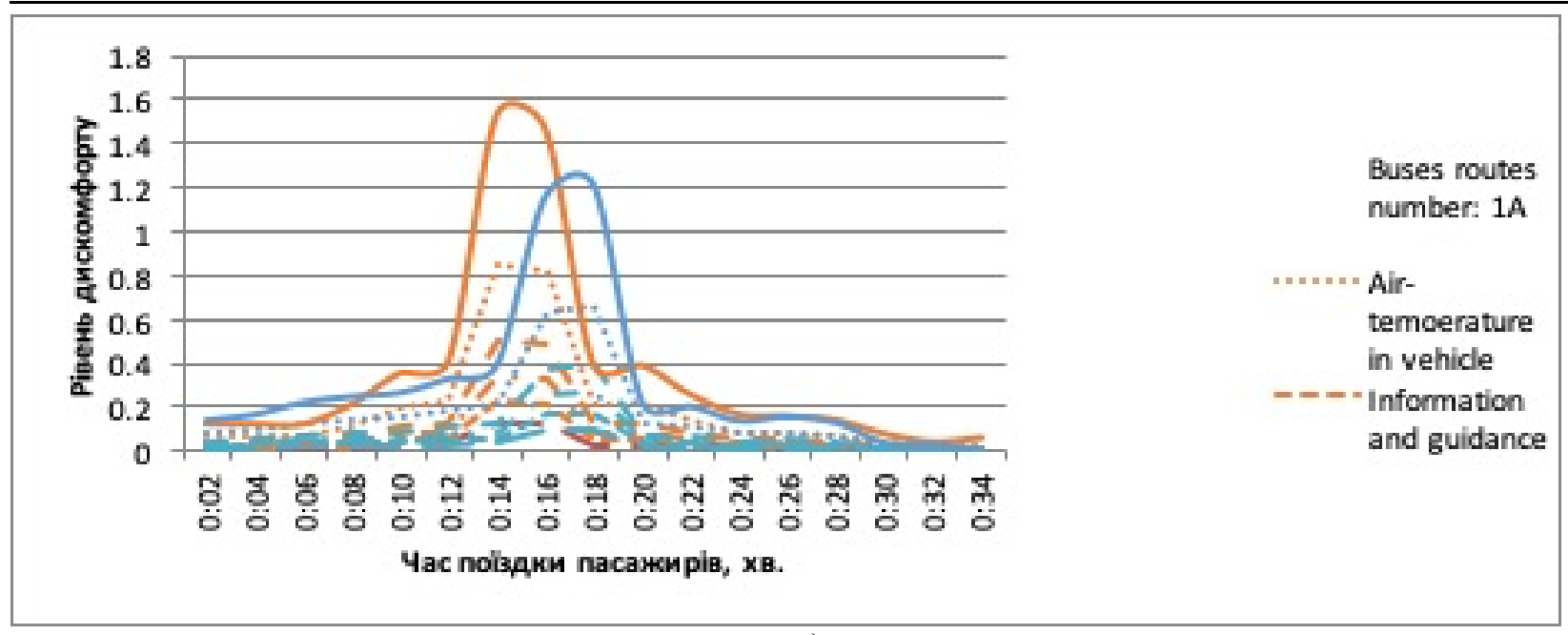

a)

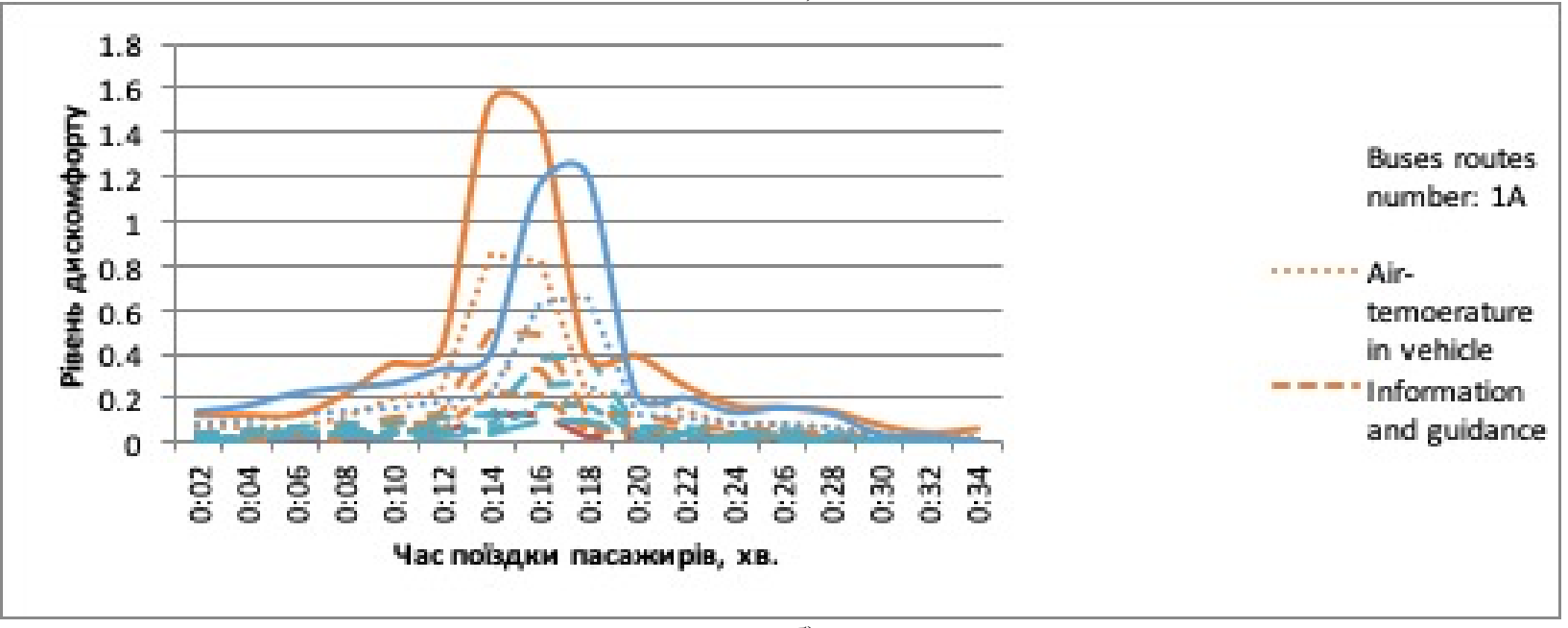

б)

Рисунок 4. Аналіз рівня дискомфорту за часом у поїздці маршрутом громадського пасажирського транспорту: а) прямі маршрути; б) зворотні маршрути

При реалізації (3), рис. 4, компонентним аналізом досліджено функції дискомфорту в часі поїздки дослідженими маршрутами вказаного виду транспорту для прямої та зворотної поїздок. Функції рівнів дискомфорту під час поїздок наведені на рисунках 4 та 5. Як видно 3 графіків, кількісні показники за величиною комфорту змінюються найбільше у залежності від наповнення салону, температури повітря в салоні та комфорту від сидіння пасажирів. Однак зручність транспорту не обов'язково означає вибір пасажирів. Індекс також може бути корисним для порівняння комфортності видів громадського транспорту для конкретних досліджуваних міст.

Дослідженнями [9-11] встановлено, що приватний автомобіль $є$ важливим 3 причини, що володіння і поїздки таким транспортним засобом представляють традиційні культурні і психологічні цінності, статус, також самостійне водіння $\epsilon$ психологічною перевагою над громадським транспортом, окремі групи населення з таких причин зупиняють вибір на автомобілі.

\section{ВИСНОВКИ}

Потреба в мобільності населення міст $є$ однією з базових потреб, яку необхідно якісно забезпечити. На базі проведених у м. Тернополі натурних досліджень з застосуванням визначників комфорту та вагових коефіцієнтів визначено кількісні показники сприйняття комфорту в мережі громадського транспорту м. Тернополя, що може бути використано для прогнозування поведінки пасажирів при користуванні громадським транспортом у середніх містах. Результати досліджень можуть бути використані як інструмент при плануванні і експлуатації транспортної мережі міста. Визначено, що сумарний рівень комфортності в системі громадського транспорту м.Тернополя $\epsilon$ змінною величиною, що залежить від семи факторів, найважливішим з яких $є$ щільність пасажирів в салоні транспортного засобу натовпу. Враховуючи встановлені шляхом мультикритеріального 
аналізу транспортної мережі характерні для середніх міст показники перевезень людей у громадах рівень дискомфорту, коефіцієнт заповнення транспортного засобу, середній час перевезення, середню відстань перевезення, для оптимального проектування мереж громадського транспорту доцільно враховувати вказану множину показників комфорту.

1.https://nacto.org

\section{ПЕРЕЛІК ДЖЕРЕЛ ПОСИЛАННЯ}

2.Шевчук О. С. Порушення при облаштуванні паркувальних місць транспортних засобів на вулично-дорожній мережі міста// Сучасні технології в машинобудуванні та транспорті. - 2016. - № 1. - C. 167-171.

3.ДБН .2.2-12:2019 Планування та забудова територій: https://dbn.co.ua/pay/pub01/dbn-B2212_planuvannya.pdf

4.http://database.ukrcensus.gov.ua/PXWEB2007/ukr/publ_new1/2019/zb_chnn2019.pdf

5.https://businessforsmartcities.com/load/118/presentation/7_sergiy_nadal_6_852c9.pdf

6.https://www.eway.in.ua/ua/cities/ternopil

7.http://bus.ck.ua/avtobus.html

8.Шевчук О.С. Вплив показників ефективності на безпеку руху вулично-дорожними мережами/ О.С. Шевчук // Вісник ХНТУСГ. - Харків, 2016. - № 169. - С. 205- 209.

9.Palma, A. d., Kilani, M., \& Proost, S. (2014). Discomfort in mass transit and its implication for scheduling and pricing. Transportation Research Part B , 1-18.

10.Qin, F. (2014). Investigating the In-Vehicle Crowding Cost Functions for Public Transit Modes. Hindawi Publishing Corporation Mathematical Problems in Engineering , 1-13.

11.Şükrü İmre and Dilay Çelebi. (2017). Measuring Comfort in Public Transport: A case study for Istanbul. Transportation Research Procedia, 25, 2441-2449.

12.Popovych P, Lyashuk O, Shevchuk O, et al. (2017). Influence of organic operation environment on corrosion properties of metal structure materials of vehicles. INMATEH - Agric Eng, 52(2), 113-118.

13.Lytvynenko, I.V., Maruschak, P.O., Lupenko, Popovych P.V. (2016). Modeling of the Ordered Surface Topography of Statically Deformed Aluminum Alloy. Mater Sciense, 52, 113-122.

14.Popovych, P., Shevchuk, O., Dzyura, V., Poberezhna, L., Dozorskyy, V., Hrytsanchuk, A. (2018). Assessment of the Influence of Corrosive Aggressive Cargo Transportation on Vehicle Reliability. International Journal of Engineering Research in Africa 38, 17-25.

15.Maruschak, P., Poberezny, L., Prentkovskis, O., Bishchak, R., Sorochak, A., \& Baran, D. (2018). Physical and mechanical aspects of corrosion damage of distribution gas pipelines after long-term operation. Journal of failure analysis and prevention, 18(3), 562-567.

16. Yavorskyi, A. V., Karpash, M. O., Zhovtulia, L. Y., Poberezhny, L. Y., Maruschak, P. O., \& Prentkovskis, O. (2016). Risk management of a safe operation of engineering structures in the oil and gas sector. In Proceedings of the 20th International Scientific Conference „Transport Means, 370-373.

17.B. Sokil, O. Lyashuk, M. Sokil, et.al (2018). Dynamic Effect of Cushion Part of Wheeled Vehicles on Their Steerability. International Journal of Automotive and Mechanical Engineering, 15.1, 4880-4892.

18.Sekulić, D., Dedović, V., Rusov, S., Obradović, A., Šalinić, S. (2016). Definition and determination of the bus oscillatory comfort zones. Int. J. Ind. Ergon. 53, 328-339.

19.https://www.citylab.com/transportation/2020/05/commute-car-traffic-transit-bike-remote-workcoronavirus/611365/?fbclid=IwAR3Ykbyf9yWC9jJhI-

5tMk49jecimXa7zsOy1TgBUpBVUM1ZSXeHjNpMS_I

20.Міністерство інфрастуктури України [Електронний ресурс]. - Режим доступу : http://www.mintrans.gov.ua.

1.https://nacto.org

\section{REFERENCES}

2.Shevchuk, O.S. (2016). Porushennya pry`oblashtuvanni parkuval`ny`x miscz` transportny`x zasobiv na vuly`chno-dorozhnij merezhi mista. Suchasni texnologiyi v mashy`nobuduvanni ta transporti, 1, 167-171.

3.DBN B.2.2-12:2019 Planuvannya ta zabudova tery`torij: https://dbn.co.ua/pay/pub01/dbn-B-

2212_planuvannya.pdf

4.http://database.ukrcensus.gov.ua/PXWEB2007/ukr/publ_new1/2019/zb_chnn2019.pdf

5.https://businessforsmartcities.com/load/118/presentation/7_sergiy_nadal_6_852c9.pdf

6.https://www.eway.in.ua/ua/cities/ternopil 
7.http://bus.ck.ua/avtobus.html

8.Shevchuk, O.S. (2016). Vplyv pokaznykiv efektyvnosti na bezpeku ruhu vulychno-dorozhnymy merezhamy. Visnyk HNTUSG, 169, 205-209.

9.Palma, A. d., Kilani, M., \& Proost, S. (2014). Discomfort in mass transit and its implication for scheduling and pricing . Transportation Research Part B , 1-18.

10.Qin, F. (2014). Investigating the In-Vehicle Crowding Cost Functions for Public Transit Modes. Hindawi Publishing Corporation Mathematical Problems in Engineering, 1-13.

11.Şükrü İmre and Dilay Çelebi. (2017). Measuring Comfort in Public Transport: A case study for Istanbul. Transportation Research Procedia, 25, 2441-2449.

12.Popovych P, Lyashuk O, Shevchuk O, et al. (2017). Influence of organic operation environment on corrosion properties of metal structure materials of vehicles. INMATEH - Agric Eng, 52(2), 113-118.

13.Lytvynenko, I.V., Maruschak, P.O., Lupenko, Popovych P.V. (2016). Modeling of the Ordered Surface Topography of Statically Deformed Aluminum Alloy. Mater Sciense, 52, 113-122.

14.Popovych, P., Shevchuk, O., Dzyura, V., Poberezhna, L., Dozorskyy, V., Hrytsanchuk, A. (2018). Assessment of the Influence of Corrosive Aggressive Cargo Transportation on Vehicle Reliability. International Journal of Engineering Research in Africa 38, 17-25.

15.Maruschak, P., Poberezny, L., Prentkovskis, O., Bishchak, R., Sorochak, A., \& Baran, D. (2018). Physical and mechanical aspects of corrosion damage of distribution gas pipelines after long-term operation. Journal of failure analysis and prevention, 18(3), 562-567.

16. Yavorskyi, A. V., Karpash, M. O., Zhovtulia, L. Y., Poberezhny, L. Y., Maruschak, P. O., \& Prentkovskis, O. (2016). Risk management of a safe operation of engineering structures in the oil and gas sector. In Proceedings of the 20th International Scientific Conference „Transport Means, 370-373.

17.B. Sokil, O. Lyashuk, M. Sokil, et.al (2018). Dynamic Effect of Cushion Part of Wheeled Vehicles on Their Steerability. International Journal of Automotive and Mechanical Engineering, 15.1, 4880-4892.

18.Sekulić, D., Dedović, V., Rusov, S., Obradović, A., Šalinić, S. (2016). Definition and determination of the bus oscillatory comfort zones. Int. J. Ind. Ergon. 53, 328-339.

19.https://www.citylab.com/transportation/2020/05/commute-car-traffic-transit-bike-remote-workcoronavirus/611365/?fbclid=IwAR3Ykbyf9yWC9jJhI5tMk49jecimXa7zsOy1TgBUpBVUM1ZSXeHjNpMS_I

20.Ministerstvo infrastruktury Ukrai'ny, official website, available at: www.mintrans.gov.ua

\section{P. Popovych, O. Shevchuk, L. Poberezhny, I. Murovanyi, P. Prohnii, L. Poberezhna, V.Plotytsia. Research of comfort in public transport of Ternopil}

The comfort of public transport in the EU is controlled by the quality standard EN 13816 - a standard of public transport service, which assesses the level of passenger satisfaction on a list of factors such as convenience, accessibility, information, time / duration, customer service, ride comfort, safety and environmental impact. ISO 2631-1 regulates the observance of mechanical parameters (noise level from rolling wheels, etc.), so it is used in the design of vehicles. It is well known that in Ukraine, when designing transport networks, only the duration of the passenger's trip to the destination is taken into account. Although passenger comfort and safety are basic factors in demand for public transport, an indicator such as convenience is usually neglected in the design of medium-sized transport systems, although in practice passengers' choice of public transport is determined by many factors.Despite the fact that comfort is one of the most important factors in shaping the demand for public transport, the convenience factor is often neglected in the design of transport networks, as well as in the assessment of performance. In urban passenger transport, in particular for medium-sized cities, passengers' choice of mode of transport for travel depends, in addition to the duration of the trip, also on many important indicators. To improve the understanding of quantitative and qualitative indicators when using public transport, the transport service should be designed so that it corresponds to the level of services expected by customers, which will ensure optimal capitalization in the implementation of transport services. This study is the basis for the formation of a policy of passenger transport by public transport from the standpoint of maximum comfort of the population with the development of basics for measuring the perception of the most important factors of public transport convenience, minimum discomfort and maximum safety. On the basis of field research using the determinants of discomfort and weights, quantitative indicators of the perception of comfort in the public transport network of Ternopil were determined, which can be used to predict the behavior of passengers in the use of public transport. It is determined that the total level of comfort in the public transport system of Ternopil is variable depending on many factors, the most important of which is the density of passengers in 
the passenger compartment during rush hour, although for optimal design of public transport networks it is advisable to take into account many comfort indicators. A private car is important because owning and traveling such a vehicle is a traditional cultural and psychological value, status, and self-driving is a psychological advantage over public transport, some groups for this reason stop choosing a car. The results of the study are the basis for understanding the attitude of passengers and the perception of comfort in urban public transport services, they can be used as a tool in the planning and operation of transport networks of medium-sized cities.

Keywords: passenger transportation, route, comfort level, public transport, passenger traffic.

ПОПОВИЧ Павло Васильович, доктор технічних наук, професор, професор кафедри спеціалізованих комп'ютерних систем, Західноукраїнський національний університет, Тернопіль, Україна, e-mail: PPopovich@ukr.net. https://orcid.org/0000-0001-5516-852X

ПОБЕРЕЖНИЙ Любомир Ярославович, доктор технічних наук, професор, професор кафедри хімії, Івано - Франківський національний технічний університет нафти і газу, Івано - Франківськ, Україна, e-mail: lubomyrpoberezhny@gmail.com. https://orcid.org/0000-0001-6197-1060

МУРОВАНИЙ Ігор Сергійович, кандидат технічних наук, доцент, завідувач кафедри автомобілів і транспортних технологій, Луцький національний технічний університет, Луцьк, Україна, e-mail: igor_lntu@ukr.net. https://orcid.org/0000-0002-9749-980X

ШЕВЧУК Оксана Степанівна, кандидат технічних наук, доцент, доцент кафедри спеціалізованих комп'ютерних систем, Західноукраїнський національний університет, Тернопіль, Україна, e-mail: oksana_shevchuk84@ukr.net. https://orcid.org/0000-0001-8283-4620

ПРОГНІЙ Павло Богданович, кандидат технічних наук, ст.викл. кафедри спеціалізованих комп'ютерних систем, Західноукраїнський національний університет, Тернопіль, Україна, e-mail: PPopovuch@gmail.com

ПОБЕРЕЖНА Любов Ярославівна, кандидат технічних наук, доцент, доцент кафедри екології, Івано - Франківський національний технічний університет нафти і газу, Івано - Франківськ, Україна, e-mail: lubomyrpoberezhny@gmail.com. https://orcid.org/0000-0002-4944-0192

ПЛОТИЦЯ Володимир Мирославович, магістрант кафедри транспортних технологій та механіки, Тернопільський національний технічний університет імені Івана Пулюя, Тернопіль, Україна, e-mail: xr5067695@gmail.com

Pavlo POPOVYCH, Doctor of Sciences, Professor, Professor of Specialized Computer Systems department, West Ukrainian National University, Ternopil, Ukraine, e-mail: PPopovich@ukr.net. https://orcid.org/0000-0001-5516-852X

Lubomyr POBEREZHNY, Doctor of Sciences, Professor, Professor of Chemistry department, IvanoFrankivsk National Technical University of Oil and Gas, Ivano-Frankivsk, Ukraine, e-mail: lubomyrpoberezhny@gmail.com. https://orcid.org/0000-0001-6197-1060

Igor MUROVANYI, Doctor of Philosophy, Associate Professor, Head of the Department of Automobiles and Transport Technologies, Lutsk National Technical University, Lutsk, Ukraine, e-mail: igor_lntu@ukr.net. https://orcid.org/0000-0002-9749-980X

Oksana SHEVCHUK, Doctor of Philosophy, Associate Professor, Associate Professor of Specialized Computer Systems department, West Ukrainian National University, Ternopil, Ukraine, e-mail: oksana_shevchuk84@ukr.net.https://orcid.org/0000-0001-8283-4620

Pavlo PROHNII, Doctor of Philosophy, Senior Lecturer of Specialized Computer Systems department, West Ukrainian National University, Ternopil, Ukraine, e-mail: PPopovuch@gmail.com

Liubov POBEREZHNA, Doctor of Philosophy, Associate Professor, Associate Professor of Ecology department, Ivano-Frankivsk National Technical University of Oil and Gas, Ivano-Frankivsk, Ukraine, email: lubomyrpoberezhny@gmail.com. https://orcid.org/0000-0002-4944-0192

Volodymyr PLOTYTSIA, Master's student of the Department of Transport Technologies and Mechanics Ternopil Ivan Puluj National Technical University, Ternopil, Ukraine, e-mail: xr5067695@gmail.com

DOI: 10.36910/automash.v2i15.396 